\title{
Spatial Distribution of Tibraca limbativentris (Heteroptera: Pentatomidae) in Babassou Palms
}

\author{
Elizabeth Araújo Costa \\ State University of Maranhão (UEMA), São Luís, MA, Brazil \\ (98) 2016-8150, Ramal 5046, Email: elizacosta17@yahoo.com.br
}

Raimunda Nonata Santos Lemos (Corresponding author)

State University of Maranhão (UEMA), São Luís, MA, Brazil

(98) 2016-8150, Ramal 5046, Email: rlemos@cca.uema.br

Keneson Klay Gonçalves Machado

State University of Maranhão (UEMA), São Luís, MA, Brazil

(98) 2016-8150, Ramal 5046, Email: kenesonk@ gmail.com

Gislane da Silva Lopes

State University of Maranhão (UEMA), São Luís, MA, Brazil

(98) 2016-8150, Ramal 5046, Email: gslopes11@yahoo.com.br

Janaina Marques Mondego

State University of Maranhão (UEMA), São Luís, MA, Brazil

(98) 2016-8150, Ramal 5046, Email: janainamondego@yahoo.com.br

Anne Caroline Bezerra dos Santos

State University of Maranhão (UEMA), São Luís, MA, Brazil

(98) 2016-8150, Ramal 5046, Email: annecaroline.bsantos@gmail.com

Mário Luiz Ribeiro Mesquita 
State University of Maranhão (UEMA), São Luís, MA, Brazil

(98) 2016-8150, Ramal 5046, Email: mario-mesquita51@ @otmail.com

\begin{abstract}
José Alexandre Freitas Barrigossi
Empresa Brasileira de Pesquisa Agropecuária (Embrapa), Embrapa Arroz \& Feijão, Santo Antônio de Goiás, Goiania, GO, Brazil. Email: jose.barrigossi@embrapa.br
\end{abstract}

Received: February 8, 2021 Accepted: May 29, 2021 Published: June 10, 2021

doi:10.5296/jas.v9i2.18739

URL: https://doi.org/10.5296/jas.v9i2.18739

\begin{abstract}
The babassou plant (Attalea speciosa Mart. Ex. Spreng, Arecaceae) is an important palm tree in the state of Maranhão, northeastern Brazil. This plant is the main arboreal component in extensive geographical areas including agricultural areas. However, limited research studies exist on its role as an alternative pest host in this region. This study investigated the occurrence of Tibraca limbativentris Stal (1860) in young babassou palm trees, the effect of abiotic factors (temperature, solar radiation and rainfall) on the number of $T$. limbativentris adults and postures, and this insect's spatial arrangement during the rice crop off-season. The research team inspected young babassou plants on a monthly basis in 2012 and 2013 to collect and quantify postures and adults. They collected a total of 1418 live adults, 13 dead and ten postures of T. limbativentris. There was a significant difference between the first and the other collections of live adults carried out in 2012 and 2013. Abiotic factors including rainfall, temperature and solar radiation, had no influence on the number of adults (alive and dead) and postures. The semivariogram adjusted to the Gaussian model showed that in 2013, the spatial distribution of living adults, that had an aggregate pattern, was highly dependent on the season. However, in 2012 there was a pure nugget effect. These results imply that young babassou plants are alternative $T$. limbativentris hosts.
\end{abstract}

Keywords: Attalea speciosa, geostatistics, kriging, spatial arrangement, stink bug

\title{
1. Introduction
}

The northern region of Maranhão, northeastern Brazil, has extensive babassou palm trees (Attalea speciosa Mart. Ex. Spreng, Arecaceae). These trees constantly transform during rice crop implantation periods. The area's farmers practice a cultivation system that combines subsistence agriculture, artisanal fishing and extraction. This system uses fire to clean and fertilize the soil by leaving the residual ash from burning the fallow bushes on the ground. Such techniques have made the state of Maranhão the largest rice producer in the northeast Brazilian region. Furthermore, this state ranks second among states with the most extensive 
rice plantations in the country (CONAB, 2019).

The phytophagous bugs are pests of economic importance to rice farmers. This fact is mainly true for the thatched bugs, the hornbills, Tibraca limbativentris Stal, 1860 (Heteroptera: Pentatomidae) that are the main pests in South America (Panizzi, 2015). This pentatomid contributes to up to $90 \%$ of farmer's productivity losses (Souza et al., 2008). The pest's adults and nymphs feed on the plant's vegetative and reproductive phases resulting in the symptoms of a dead heart and a white panicle, respectively (Botton et al., 1996). Therefore, the bug causes the most damage in the rice crop's reproductive phase (Krinski \& Foerster, 2017). The bug is also known as "cangapara" in the state of Maranhão. This bug is found in almost all the state's municipalities that grow upland rice.

Due to these bugs' polyphagy, they seek alternative plant hosts to feed, oviposition and develop their offspring (Panizzi, 1991); thus, they hibernate in adjacent crop remains or alternative host plants waiting for the next rice crop. A behavior confirmed by Pasini et al. (2018) who demonstrated the root bug in clumps of foxtail grass, Andropogon bicornis $\mathrm{L}$ and A. lateralis (Poaceae) in the rice crop's off-season period. According to Engel et al. (2019), these alternative resource sources help bugs survive unfavorable periods.

Because they are highly resistant to fire, babassou plants are the dominant species in Maranhão's cultivation areas after a rice harvest (Mitja et al., 2018). Therefore, the babassou palm may be a potential shelter for T. limbativentris in the off-rice season.

Advances in integrated pest management have permitted study of the spatial distribution of some bug species in agricultural areas to construct infestation maps for targeted and precise application of population reduction measures. For instance, the spatial distribution of $T$. limbativentris adults and nymphs in irrigated rice fields depends on the crop's phenological stage (Costa et al., 2019; Pasini et al., 2020; Pasini et al., 2021). Engel et al. (2021), point out that the spatial distribution study in alternative hosts helps in pest permanent monitoring and anticipating possible outbreaks.

Despite the potential economic damage caused by bugs, scarce information exists on its spatial distribution in alternative hosts. Therefore, this research aimed to describe the distribution of $T$. limbativentris in young babassou plants adjacent to rice growing areas in the northern region of the state of Maranhão. This study also investigated the influence of abiotic factors (temperature, solar radiation and rainfall) on the number of the pests' adult populations and spawnings and the insect's spatial distribution in the area inter-harvest period.

\section{Material and Method}

\subsection{Study Area: Location and Characteristics}

The research team conducted a study in the municipality of Matões do Norte (latitude

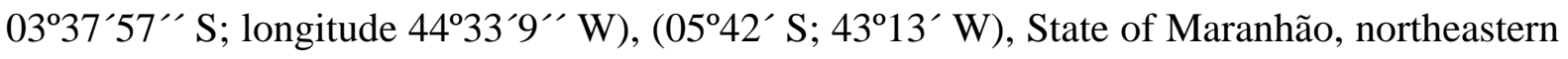
Brazil. They did the research in areas where family farmers cultivated upland rice intercropped with corn (Zea mays L.) and cassava (Manihot esculenta Crantz). 


\section{Macrothink

Thorntwaite's classification describes the region's climate as type ( $\left.\mathrm{C}_{1} \mathrm{SA}^{\prime} \mathrm{a}\right)$, sub-humid, mega-thermal, dry climate with a moderate water deficit in the summer (Geplan, 2002; Barros et al., 2012).

\subsection{Climatic Data}

The study team obtained the average 30 days' temperature $\left({ }^{\circ} \mathrm{C}\right)$, solar radiation $\left(\mathrm{cal} \mathrm{cm}^{-2}\right.$ day) and rainfall $(\mathrm{mm})$ from the Meteorological Laboratory of the Geoenvironmental Nucleus of the Maranhão State University (Figure 1).

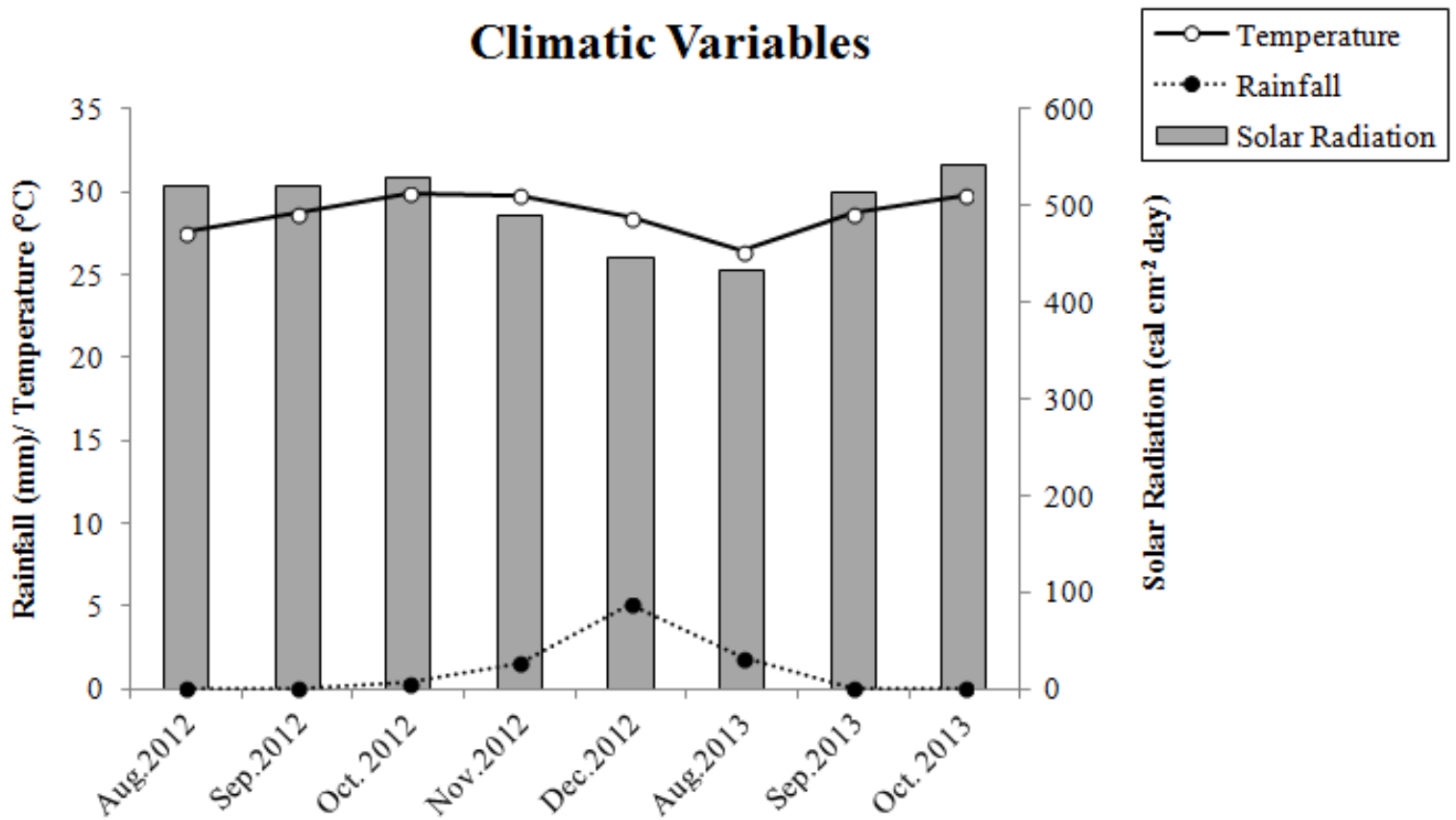

Collections

Figure 1. Average temperature $\left({ }^{\circ} \mathrm{C}\right)$, solar radiation (cal $\mathrm{cm}^{-2}$ day) and rainfall $(\mathrm{mm})$ in 2012 and 2013, in the municipality of Matões do Norte, State of Maranhão, northeastern Brazil

\subsection{Sampling of T. limbativentris}

The team collected samples each month after the rice harvest from August to December 2012 and August to October 2013. Each year, they selected an area measuring approximately four hectares surrounded by young babassou palms as their study sample. The areas' predominant cultivation system was "slash and burn", where vegetation was cut, burnt to clean the site and the ash used as a soil fertilizer. This soil preparation generally occurred in November, followed by rice sowing in January to coincide with the beginning of the region's rainy season. Nevertheless, the areas were kept fallow for vegetation regeneration after a rice harvest.

The selected young babassou plants (called pindovas), measuring $60 \mathrm{~cm}$ in height and $52 \mathrm{~cm}$ in diameter, were the most vigorous plants located equidistantly (approximately $5 \mathrm{~m}$ apart) within the rice planting area. 
The team randomly selected pindovas' sampling points following a zigzag pattern covering the entire area related to the rice clump studied.

The team marked 64 and 49 pindovas in 2012 and 49 in 2013. They meticulously inspected pindovas leaves and trunk for the presence and collection of live and dead adult bugs, and $T$. limbativentris postures

\subsection{Georeferencing of Sampled Plants}

The study used a Garmin MAP 76CSX GPS (Global Positioning System) device to georeference the selected babassou plants for T. limbativentris sampling. The device used the flat coordinates of the Universal Transverse Mercator System (UTM) to identify the palm trees' location and facilitate repeated sampling from the same plants.

\subsection{Statistical Analysis}

First, the Shapiro-Wilks normality test was used to describe data collected on adult bugs (living and dead) and postures. Then, since data was non-normal, the Kruskal-Wallis non-parametric test, $\mathrm{p}<0.05$ (Statsoft Inc, 2011), was used to identify statistical differences between the number of adults (living and dead) and collected postures.

Subsequently, the number of live and dead adults and postures were transformed into their square roots $(\sqrt{ } \mathrm{x})$ and tested using the T-test at the level of $5 \%$ probability in the BioEstat 5.0 program (Ayres et al., 2007). Finally, pearson's linear correlation was used to describe the relationship between abiotic factors (temperature, solar radiation and rainfall) and the number of adults (living and dead) and postures.

\subsection{Geostatistical Analysis}

A Geostatistical analysis was used to construct semivariograms and verify spatial dependence between samples. According to Cambardella et al. (1994), the [(Co / C1 + Co) x100] model's degree of spatial dependence is considered strong if this ratio is $\leq 25 \%$, moderate if it is between 25 and $75 \%$, and weak when the ratio is $>75 \%$. Subsequently, the variograms were constructed using the model with the best determination coefficient.

\subsection{Preparation of Spatial Distribution Maps}

The study developed spatial distribution maps using all the annual data on live adult bugs. The data obtained were imported into SAS version 8.2 (SAS Institute, 2001) for analysis then, crossed and interpolated. In addition, bug infestation maps were generated using the G.S. + program (Gamma Design Software, 2000).

\section{Results and Discussion}

A total of 1418 live adults, 13 dead and 10 postures of T. limbativentris were collected in 2012 and 2013. The high number of live individuals collected from the pindovas suggests the presence of a surviving $T$. limbativentris population large enough to infest the same rice fields the following year. Bugs infest rice plants within 20 or more days of emergence and begin oviposition ten days later (Ferreira, 1998), with the possibility of reproducing up to three 
generations in a rice crop (Pasini et al., 2018).

On the one hand, the 2012 results concerning 1304 live adults, 5 dead and 9 postures indicate that a farmer should use preventive measures, such as resistant cultivars or trap plants, to minimize the damage of $T$. limbativentris if he or she intends to reuse the area to plant rice.

On the other hand, the 2013 results had fewer collections (114 live adults, 8 dead and 1 posture) as the fallow period was not maintained because farmers needed to prepare the area for the next planting. The presence of postures in the two years suggests that palm trees are a refuge for $T$. limbativentris adults that preserve its population. Based on research by Fuentes-Rodríguez et al. (2019), the fact that T. limbativentris nymphs do not dwell in alternative hosts implies that the pest needs a rice plant to reproduce

The team observed a significant difference in the number of living adults in the first and the other collections in 2012 and 2013 (Figure 2). The first collection of each year had a higher average number of living adults but similar numbers of dead adults and postures to the collections made the rest of each year (Figure 2).
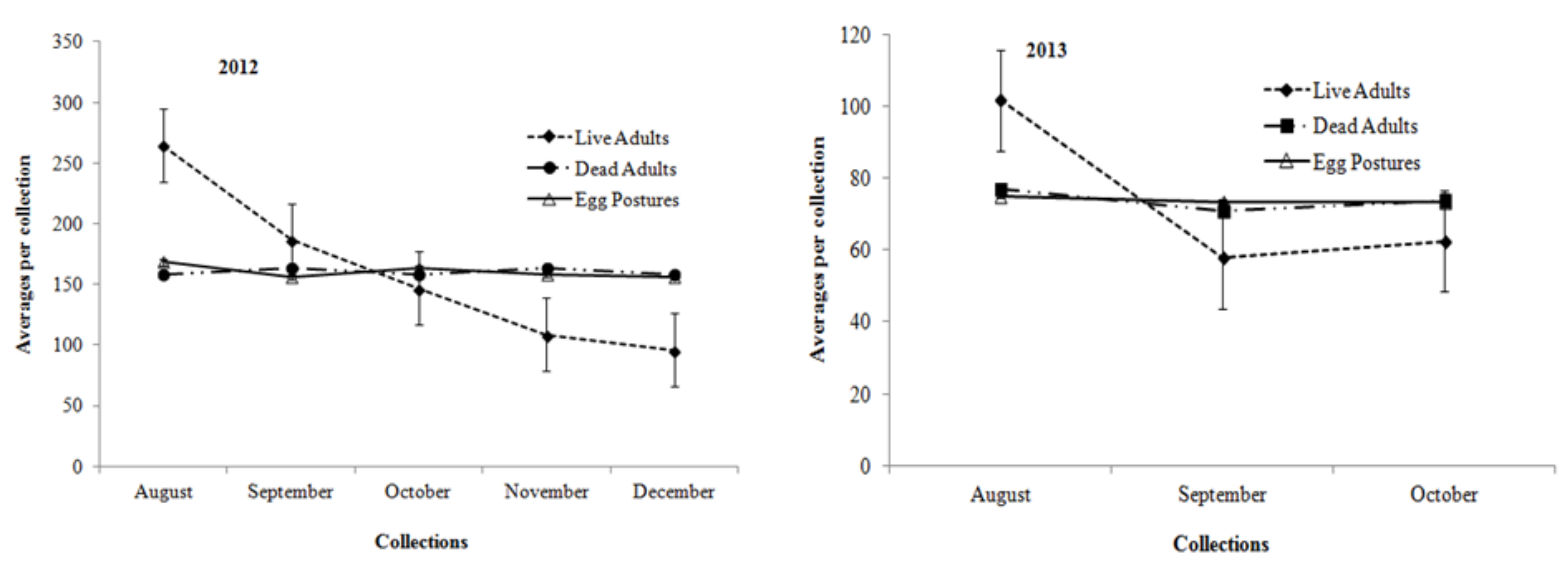

Figure 2. The average number of adults (alive and dead) and postures of Tibraca limbativentris collected in young babassou plants during the rice crop off-season in the municipality of Matões do Norte, State of Maranhão, northeastern Brazil in 2012 and 2013

Therefore, it is possible to infer that young babassou plants present microclimatic conditions that favor the survival of the T. limbativentris population. According to Klein et al. (2013), a protected environment is a better shelter since it provides more stable microclimates than the open environments.

The rainfall, temperature and solar radiation did not influence the number of adults (alive and dead) and postures collected between August and December 2012, and August and October 2013 (Table 1).

The absence of a correlation or presence of low correlation between climatic factors and pest populations may indicate that these abiotic factors did not affect the area's $T$. limbativentris population. However, the number of T. limbativentris adults and postures in each collection was insufficient to illustrate the influence of abiotic factors on this insect-pest's population. 


\section{IIMacrothink}

Table 1. Pearson correlation coefficients showing the relationship between the number of adults (alive and dead) and postures of Tibraca limbativentris collected from young babassou plants during the rice inter-harvest period in the municipality of Matões do Norte, State of Maranhão, northeastern Brazil in 2012 and 2013

\begin{tabular}{lll}
\hline Climatic data & Biological material & Pearson Correlation Index \\
\hline Temperature & Live adults & $-0.76^{\mathrm{ns}}$ \\
& Dead adults & $0.03^{\mathrm{ns}}$ \\
& Postures & $-0.31^{\mathrm{ns}}$ \\
Rainfall & Live adults & $-0.54^{\mathrm{ns}}$ \\
& Dead adults & $-0.45^{\mathrm{ns}}$ \\
& Postures & $-0.53^{\mathrm{ns}}$ \\
Solar & Live adults & $0.50^{\mathrm{ns}}$ \\
Radiation & Dead adults & $0.27^{\mathrm{ns}}$ \\
\hline
\end{tabular}

${ }^{n s}$ Non-significant according to Pearson's correlation coefficients ( $\mathrm{r}$ ) tested by the $\mathrm{T}$ test at a $5 \%$ probability level.

Based on the above parameters, nugget effect, level and range for the period correspondent to the year 2012, there was a random pest distribution in the babassou young plants (Table 2). Thus, the appropriate model to describe the spatial behavior of adults of $T$. limbativentris was a pure nugget effect (Figure 3A).

A different research study conducted in irrigated rice fields substantiated the same distribution of adults and nymphs as T. limbativentris (Alves et al., 2016). This pure nugget effect in insect collections is due to sampling error or spatial dependence; however, this usally occurs on a smaller scale than the one we adopted (Liebhold et al., 1993). Thus, there was a random distribution of live adult bugs; alternatively, or that the distance between the sampling points in the area was too great to identify a dependent spatial distribution. This distance could be attributed to the disposition of the young babassou plants in the area. 


\section{Macrothink}

Journal of Agricultural Studies

ISSN 2166-0379

2021, Vol. 9, No. 2

Table 2. Semivariogram models showing the spatial distribution of Tibraca limbativentris live adults o collected from babassou young plants during the rice crop off-season in the municipality of Matões do Norte, State of Maranhão, northeastern Brazil in 2012 and 2013

\begin{tabular}{lllllll}
\hline Years & \multicolumn{2}{l}{ Semivariogram Parameters } & & GDE & $\mathrm{R}^{2}$ & Model \\
\cline { 2 - 4 } & Co & Co+C & $\mathrm{A}$ & & & \\
\hline 2012 & - & - & - & - & - & Pure Nugget Effect \\
2013 & 0.0001 & 0.2252 & 29.45 & 0.044 & 0.666 & Gaussian \\
\hline
\end{tabular}

Co: Nugget effect; Co+C: Level; A: Range; GDE: Degree of spatial dependence; Determination coefficient: $\mathrm{R}^{2}$

The distribution of bugs in 2013 was adjusted to the Gaussian model (Figure 3B), due to the great continuity of the variables, that is, values found very close to semivariance (Table 2). Similarly, Pazini et al. (2015) found that this model was the best that was adjusted in most $T$. limbativentris collections in irrigated rice.

In 2013, the semivariance initially increased as the distance between the sampling points increased until a point where the semivariance reached a plateau (Figure 3B). However, the semivariance for the year 2012 remained constant throughout the sampling distances (Figure $3 \mathrm{~A})$. As for the adjustment's efficiency, the Gaussian model obtained an $\mathrm{R}^{2}=0.67$; this figure indicates a good adjustment based on Silva et al. (2015). The number of adult live wire bugs collected in 2013 had a range of $29.45 \mathrm{~m}$. This parameter represents the limit of dependence on the sampled points.

Based on the criterion by Cambardella et al. (1994), the 2013 samples portrayed strong spatial dependence, because it was $\leq 25 \%$, indicating that the number of individuals depends on their position in the area. 


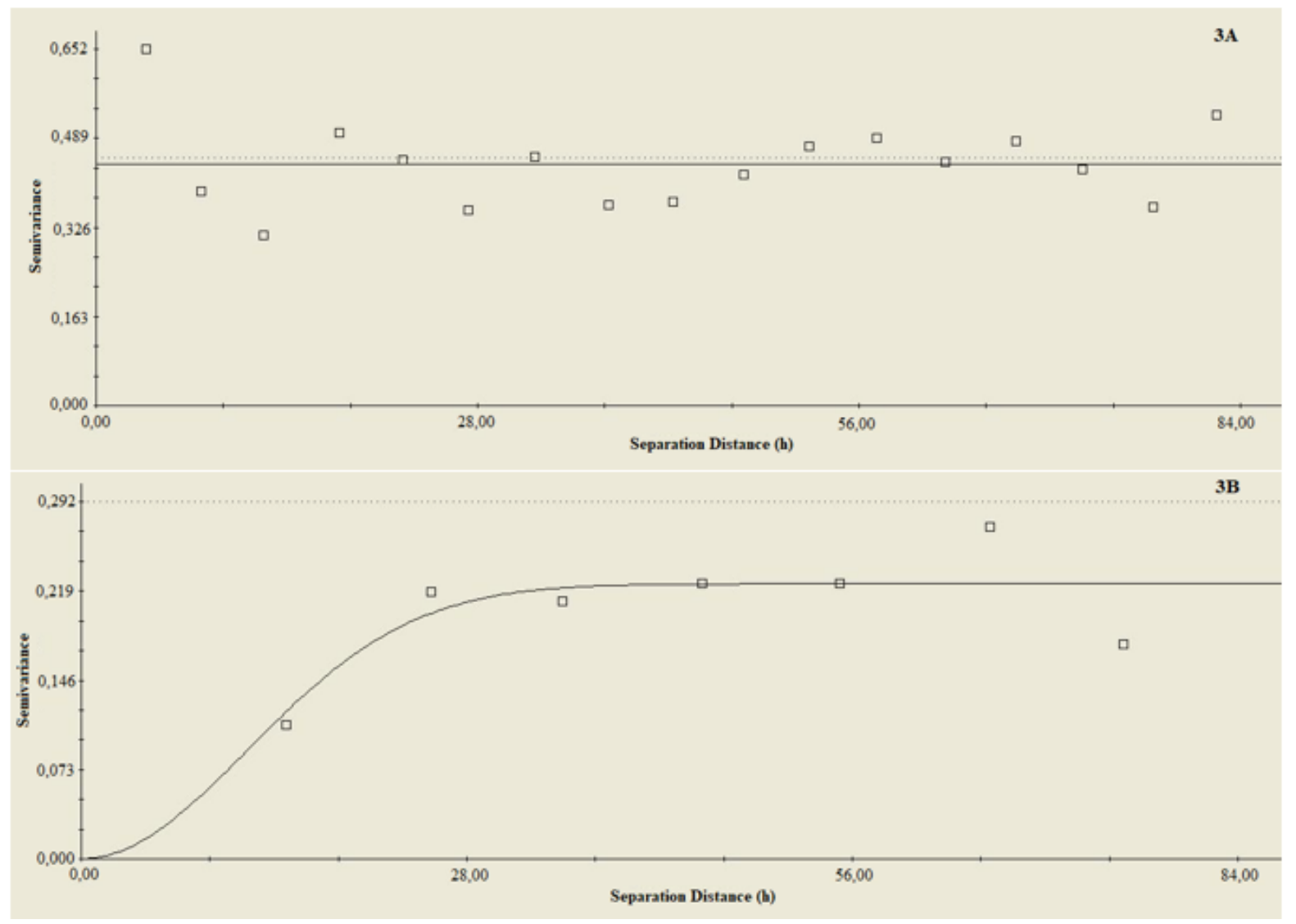

Figure 3. Semivariograms of the distribution of live adults of Tibraca limbativentris in young babassou plants during the rice inter-harvest period in the municipality of Matões do Norte,

State of Maranhão, northeastern Brazil, in 2012 (3A) and 2013 (3B)

The kriging map was generated for the year 2013 only. This map shows that the spatial distribution of $T$. limbativentris was aggregated, with a concentration of specimens in the young babassou plants located at the area's edge (Figure 4). When assessing the spatial distribution of Helicoverpa armigera (Hubner) (Lepidoptera: Noctuidae) and Pectinophora gossypiella (Saunders) (Lepidoptera: Gelechiidae), Milonas et al. (2016) reported that these pests' spatial distribution depends on the area's availability and distribution of hosts. Following this study, Martins et al. (2020) mentioned that it is possible to expand the study of insect behavior in the field from their study of the spatial distribution of Neomegalotomus parvus (Hemiptera: Alydidae). 


\section{Macrothink}

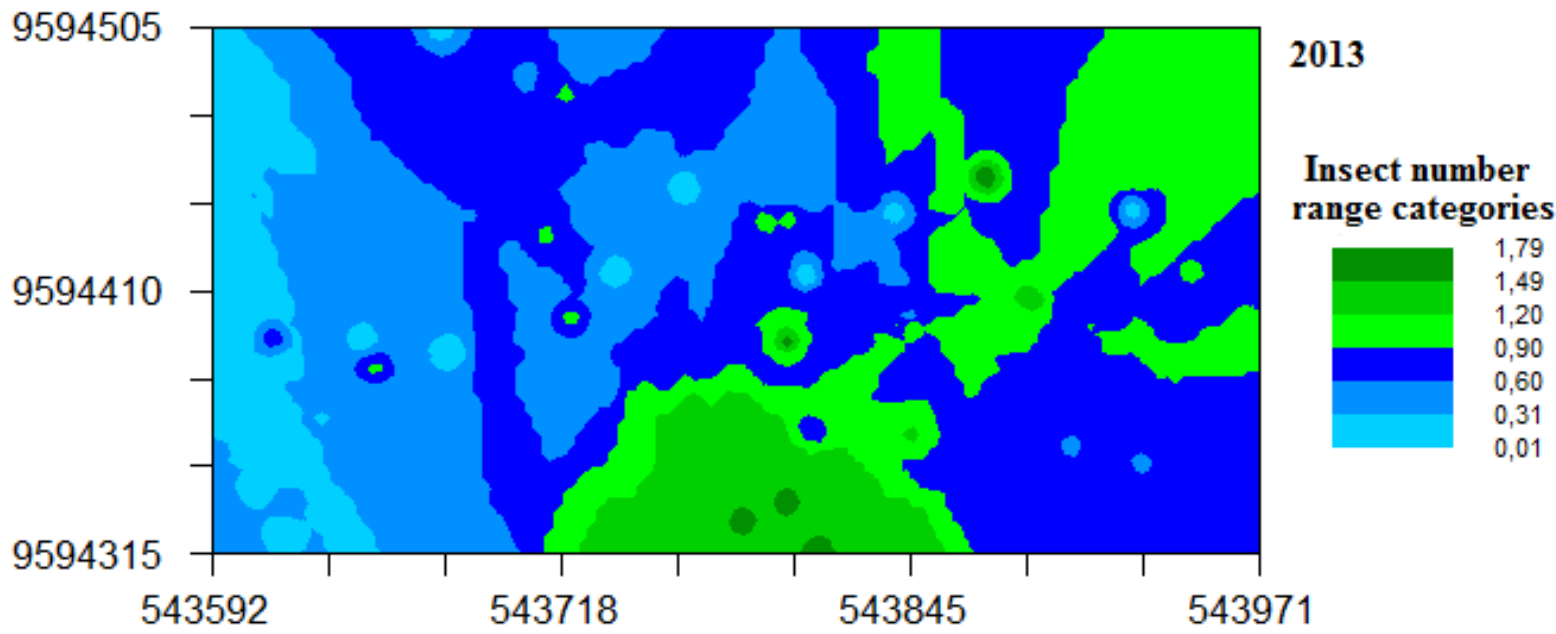

Figure 4. The Spatial distribution of Tibraca limbativentris adult population collected from young babassou plants during the rice crop off-season in the municipality of Matões do Norte, State of Maranhão, northeastern Brazil, in 2013

Young babassou plants are widely distributed on the edges and within rice-growing areas. Consequently, these plants play an essential role in T. limbativentris survival during the rice crop off-season. Therefore, program managers can focus appropriate strategies on young babassou plants to manage and control T. limbativentris to reduce this pest's incidence in the new rice planning season.

\section{Conclusions}

The young babassou plants serve as a refuge for Tibraca limbativentris in the rice crop off-season. This shelter implies that abiotic factors, such as temperature, humidity and precipitation, have no impact on the study area's insect population. Furthermore, aggregates of fully-grown $T$. limbativentris are spatially distributed in this alternative host and form ridges at the area's edge. Such a location favors sampling plans for the management and control of this pest that economically influences rice crop production.

\section{References}

Alves, T. M., Maia, A. H. N., \& Barrigossi, J. A. F. (2016). Spatial Distribution and Coexisting Patterns of Adults and Nymphs of Tibraca limbativentris (Hemiptera: Pentatomidae) in Paddy Rice Fields. Environmental Entomology, 45(6), 1-10. https://doi.org/10.1093/ee/nvw141

Ayres, M., Ayres, M. J. R., Ayres, D. L. \& Santos, A. S. (2007). BioEstat 5.0 - Aplicações estatísticas nas Áreas das Ciências Biológicas e Médicas. Belém: ONG Mamirauá. p. 364.

Barros, A. H. C., Araújo Filho, J. C., Silva, A. B., \& Santiago, G. A. C. F. (2012). Climatologia do Estado de Alagoas. Recife, 32 p. (Boletim de Pesquisa e Desenvolvimento/Embrapa Solos, 2(11). https://ainfo.cnptia.embrapa.br/digital/bitstream/item/103956/1/BPD-211-Climatologia-Alago 
as.pdf. 11 Nov. 2020.

Botton, M., Martins, J. F. S., Loek, A. E. \& Rosenthal, M. (1996). Biologia de Tibraca limbativentris sobre plantas de arroz. Anais da Sociedade Entomológica do Brasil, 25(1), 217-221. https://doi.org/10.37486/0301-8059.v25i2.1119

Cambardella, C. A., Morman, T. B., Novak, J. M., Parkin, T. B., Karlen, D. L., Turco, R. F., \& Konopka, A. E. (1994). Field-scale variability of soil properties in Central lowa Soils. Soil Science Society of America Journal, 58(5), 1501-1511. https://doi.org/10.2136/sssaj1994.03615995005800050033x

Conab - Companhia Nacional de Abastecimento (2019). Acompanhamento de safra brasileira: grãos, décimo segundo levantamento, Safra 2018/2019. Brasília. p. 158. https://www.conab.gov.br/info-agro/safras/graos/boletim-da-safra-de-graos?start=10. 25 Nov. 2020.

Costa, H. S., Seidel, E. J., Pazini, J. B., Silva, A. M., Silva, F. F., Martins, J. F. S., \& Barrigossi, J. A. F. (2019). Mapping of spatiotemporal distribution of Tibraca limbativentris Stal (Hem.: Pentatomidae) in flooded rice crop in Southern Brazil. Revista Brasileira de Entomologia, 63(3), 205-211. https://doi.org/10.1016/j.rbe.2019.04.001

Engel, E., Pasini, M. P. B., Tragnago, J. L., Hörz, D. C., Kist, N. A., Zamberlan, J. F., \& Bortolotto, R. P. (2019). Saccharum angustifolium (Nees) Trin. (Poales: Poaceae) as hibernacle for stink bugs during the soybean and corn off-season in Southern Brazil. Arquivos do Instituto Biológico, 86, 1-7, e0332019. https://doi.org/10.1590/1808-1657000332019

Engel, E., Pasini, M. P.B., \& Lúcio, A. D. (2021). Spatial distribution and sample size to estimate Euschistus heros population density in wild plants during off-season. Journal of Plant Diseases and Protection, 1, 1-8. https://doi.org/10.1007/s41348-021-00450-1

Ferreira, E. (1998). Manual de identificação de pragas do arroz. Santo Antônio de Goiás, p. 110. (Embrapa-CNPAF. Documentos, 90). https://www.embrapa.br/busca-de-publicacoes/-/publicacao/205593/manual-de-identificacaode-pragas-do-arroz. 25 Aug. 2020.

Fuentes-Rodríguez, D., Franceschini, C., Gervazoni, P., López, G., Sosa, A., \& Kruger, R. (2019). Importance of native vegetation for detection and management of rice stink bug (Tibraca limbativentris). Bulletin of Entomological Research, 110(3), 352-362. https://doi.org/10.1017/S0007485319000701

Gamma Design Software GS+. (2000). Geoestatistics for the environmental sciences. Gamma Design Software. Version 5.1 for windows, Michigan.

Geplan - Gerência de Planejamento e Desenvolvimento Econômico. (2002). Atlas do Maranhão. Laboratório de Geoprocessamento. São Luís: Universidade Estadual do Maranhão. p. 32.

Klein, J. T., Redaelli, L. R., \& Barcellos, A. (2013). Andropogon bicornis (Poales, Poaceae): a hibernation site for Pentatomoidea (Hemiptera: Heteroptera) in a rice-growing region of 
southern Brazil. Neotropical

Entomology, $\quad 42(3)$,

240-245.

https://doi.org/10.1007/s13744-013-0116-6

Krinski, D., \& Foerster, L. A. (2017). Damage by Tibraca limbativentris Stal (Pentatomidae) to upland rice cultivated in Amazon rainforest region (Brazil) at different growth stages. Neotropical Entomology, 46(1), 107-114. https://doi.org/10.1007/s13744-016-0435-5

Liebhold, A. M., \& Rossi, R. E. (1993). Geostatistics and geographic information systems in applied insect ecology. Annual Review of Entomology, 38(1), 303-27. https://doi.org/10.1146/annurev.en.38.010193.001511

Martins, I. C. F, Cividanes, F. J., Barbosa, J. C., Panizzi, A. R., Lima Junior, J. A., \& Campos, L. D. (2020). Spatio-temporal distribution of Neomegalotomus parvus (Hemiptera: Alydidae) in soybean/corn crop with beetle bank. Revista Brasileira de Ciências Agrárias, 15(2),1-9. https://doi.org/10.5039/agraria.v15i2a6323

Milonas, P., Gogou, C., Papadopoulou, A., Fountas, S., Liakos, V., \& Papadopoulous, N. T. (2016). Spatio-Temporal distribution of Helicoverpa armigera (Hubner) (Lepidoptera: Noctuidae) and Pectinophora gossypiella (Saunders) (Lepidoptera: Gelechiidae) in a cotton production area. Neotropical Entomology, 45(3), 240-251. https://doi.org/10.1007/s13744-015-0358-6

Mitja, D., Delaítre, E., Santos, A. M., Miranda, T., Coelho, R. F. R., Macedo, D. J., Demasgistri, L., \& Petit, M. (2018). Satellite images combined with field data reveal negative changes in the distribution of babassu palms after clearing off Amazonian Forests. Environmental Management, 61(2), 321-336. https://doi.org/10.1007/s00267-017-0965-6

Panizzi, A. R. (1991). Ecologia nutricional de insetos sugadores de sementes. In Panizzi, A. R. \& Parra, J. R. P. (Eds), Ecologia nutricional de insetos e suas implicações no manejo de pragas (253-287). São Paulo: Manole.

Panizzi, A. R. (2015). Growing problems with stink bugs (Hemiptera: Heteroptera: Pentatomidae): species invasive to the U.S. and potential neotropical invaders. American Entomologist, 61(4), 223-233. https://doi.org/10.1093/ae/tmv068

Pasini, M. P. B., Lúcio, A. D., Cargnelutti Filho, A., de Ribeiro, A. L. P., Zamberlan, J. F., \& Lopes, S. J. (2018). Population density of Tibraca limbativentris on flood irrigated rice and alternative host plants. Pesquisa Agropecuária Brasileira, 53(3), 265-278. https://doi.org/10.1590/s0100-204x2018000300001

Pasini, M. P.B., Engel, E., Lúcio, A. D., \& Bortolotto, R. P. (2021). Semivariogram models for rice stem bug population densities estimated by ordinary kriging. Acta Scientiarum. Agronomy, 43, e48310. https://doi.org/10.4025/actasciagron.v43i1.48310

Pasini, M. P.B., Engel, E., Lúcio, A. D., Cargnelutti Filho, A., Ribeiro, A. L. P., Bortolotto, R. P., \& Zamberlan, J. F. (2020). Spatialization of Tibraca limbativentris Stål inirrigated rice: a geostatistical approach. Arquivos do Instituto Biológico, 87, 1-11, e1202018. https://doi.org/10.1590/1808-1657001202018 
Pazini, J. B., Botta, R. A., Seidel, E. J., Silva, F. F., Martins, J. F. S., Barrigossi, J. A. F., \& Rübenich, R. (2015). Geoestatística aplicada ao estudo da distribuição espacial de Tibraca limbativentris em arrozal irrigado por inundação. Ciência Rural, 45(6), 1006-1012. https://doi.org/10.1590/0103-8478cr20140841

SAS Statsoft Inc. (2001). Statistical Analysis system for Windows 98. SAS Institute. Version 8.2, Cary.

Silva, A. G., Farias, P. R. S., Boiça Junior, A. L., Lima, B. G., Ponte, N. H. T., Pinho, R. C., \& Barbosa, R. S. (2015). Análise espacial da mosca-negra em sistema agroflorestal de citros. Comumicata Scientiae, 6(3), 350-358. https://doi.org/10.14295/cs.v6i3.408

Souza, J. R., Ferreira, E., Boiça Junior, A. L., Cargnelutti Filho, A., Chagas, E. F., \& Mondego, J. M. (2008). Avaliação de resistência em cultivares de arroz ao ataque do percevejo-do-colmo, Tibraca limbativentris Stal, 1860 (Hemiptera: Pentatomidae). Arquivos do Instituto Biológico, 45(4), 449-454. https://ainfo.cnptia.embrapa.br/digital/bitstream/item/34910/1/AIBSouza.pdf

Statsoft Inc. (2011). Statistica for Windows (Software - system for data - analyses), Statsoft Inc, Version 10.0. Tulsa.

\section{Copyright Disclaimer}

Copyright for this article is retained by the author(s), with first publication rights granted to the journal.

This is an open-access article distributed under the terms and conditions of the Creative Commons Attribution license (http://creativecommons.org/licenses/by/4.0/). 